\title{
Art For? Framing the Conversation on Art and Social Change "with" Steven Hill
}

\author{
Patti Fraser ${ }^{1}$ \\ Simon Fraser University \\ pattiafraser@gmail.com \\ Flick Harrison \\ Simon Fraser University \\ flick@flickharrison.com
}

\begin{abstract}
The research represented within this text and media art piece is based on a formal interview with director Steven Hill for the Art for Social Change Research Project. By disrupting the interview through visual inserts and pithy philosophical responses into the visual frame we are seeking to reconsider the expectations associated with research and research interviews. This visual play also furthers Steven Hill's theorizing on the idea of frames and what predetermines the frames we bring to the project of art "for" social change.
\end{abstract}

Keywords: arts-based research, socially engaged art, popular theatre, media art, drama education, Canadian theatre studies.

\footnotetext{
${ }^{1}$ Biographical statement: Patti Fraser, PhD is currently a Research Associate with the Art for Social Change Research Project at Simon Fraser University, the co-artistic Director of the Housing Matters Media Project, and the 2013 recipient of the Vancouver Mayor's Art Award for Community Engagement. www.pattifraser.com
}

Flick Harrison (B. Journ [Hons], Carleton 1994; MFA UBC 1998) is a writer, media artist, filmmaker, hacker, educator and drone pilot in Vancouver. Starting out on CBC's Road Movies as one of Canada's first professional videographers, he's since worked in Pakistan, the US, Mexico and China. With Something Collective, he helped pilot the City of Vancouver's Fieldhouse community-artist residencies. 


\section{Research Statement}

In my (Fraser's) role as researcher with Simon Fraser University's Art for Social Change Research Project, ${ }^{2}$ funded by the Social Science and Humanities Research Council of Canada, I was charged with the task of framing a historical context on the work of artists who have been recognized for their contribution to the field of socially engaged art in Canada. As a part of this larger project, media artist Flick Harrison and I recorded a series of conversations with thirteen artists, ${ }^{3}$ many of whom I shared a history of practice ${ }^{4}$ as socially engaged artists. For the purposes of this paper, I considered practice as meaning to take the experience one has gained, one's experience from the making or doing of creative practice, in order to actualize a condition or event that did not exist before.

There is currently a great deal of interest in this form of art practice within institutions and academies. The institutional gaze has brought with it tensions and questions that are not easily resolved. Who is best qualified to do this work? How are the processes and techniques, and the "way" many of these forms have evolved, used to serve agendas that are counter to the original impulses behind the work? Currently the term community engagement is even viewed with suspicion by many, as the arts-based practices born out of critical and activist sentiments are being instrumentalized and co-opted by institutions and organizations to further serve neo-liberal and progressive agendas (see for example, Balfron Social Club, 2015).

In counter-point to this argument, the art practices defined within the field and those being explored within the Art for Social Change Research Project are being seen as interactive, multidisciplinary opportunities for practice and pedagogy. These practices have the capacity to open up new spaces to encounter relationships and new ways to create ethical responses to emergent local and/or global concerns. In conversation with Dr. Lynn Fels, ${ }^{5}$ the underlying question we chose that formed the basis of the interviews I conducted with the artists, is based on Hannah Arendt's theory of past and future as it relates to the

\footnotetext{
${ }^{2}$ For the project website see: http://www.icasc.ca/

${ }^{3}$ These interviews were conducted following the protocols laid out by the Office of Research Ethics at Simon Fraser University. The final version of the video, included as part of this paper, has been reviewed by and consent given by Steven Hill for it to being published.

${ }^{4}$ The set of artistic practices that form the basis of inquiry within The Art for Social Change Research Project has been described as a spectrum of work. This spectrum contains arts practices that have been defined as participatory, socially engaged, community-engaged, collaborative, activist based and relational (Finkelpearle, 2013).

5 Lynn Fels is one of six co-investigators with Simon Fraser University's Art for Social Change Research Project.
} 
education of the young. Arendt (1954) asserts that education is inspired by a desire to renew the common world "and by the same token save it from ruin, which, except for renewal, except for the coming of the new and young, would be inevitable" (p. 196). The question I asked the artists was what in their experience as socially engaged artists needed to be preserved or held as a responsibility as this form of work is re-imagined in the future.

\section{Artist Statement}

The research outcome represented in the digital video, the centre-piece of this contribution, is based on one of the interviews taken from the entire collection of interviews conducted for the Art for Social Change Research Project. The "thought experiment" created by co-author Harrison and I, features an interview with director, actor, and creator Steven Hill. ${ }^{6}$ Steven Hill and I share a history of collaboration that dates back to the AIDS activist movement in Vancouver in the late 1980s. We collaborated together for a number of years with activist groups such as the World Aids Group ${ }^{7}$ in order to create interactive work on issues relating to AIDS, particularly with youth.

One of the challenges presented within the research project was how to represent biographical and autobiographical reflections. How can we portray a shared past that changes over time? It was during the initial development of our research that a puppet from a project Steve and I co-created in the 1980s called me to attention as it sat waiting for a new life at the top of the bookcase. This puppet became a kind of talisman of reflection and evidence of a shared past that no longer existed except within the shared memory hidden within the minds of the interviewer and interviewee. The appearance of this puppet and Steven Hill's generous willingness to unpack his notions of "art for social change" in an interview inspired this video.

By disrupting the interview through visual archival inserts and by applying pithy philosophical responses into the visual frame, I sought to rethink the conventional research interview and expose the interiority of interviewer, the one who does not speak directly to the question posed, but is fully engaged in the conversation.

We conceived of this work in order to interrupt and to re-frame the conventional expectations that lie at the heart of the relationship between researcher and research subject. Calling attention to expectations in standard research interviews where the speaker speaks and the listener listens. The work

\footnotetext{
${ }^{6}$ Steven Hill is currently Co-Artistic Director of Fight with a Stick and Associate Professor in Theatre Performance in the School for Contemporary Arts at Simon Fraser University in Vancouver, British Columbia, Canada.

${ }^{7}$ The World Aids Group was formed in the 1980s in Vancouver, BC, to provide prevention and sexual health education to youth.
} 
hints at the larger philosophical questions of the reality of inter-subjectivity, which is so often ignored in social science research. This work suggests through the visual field and textual play there is significance to the space between interviewer and interviewee. This piece not only playfully unpacks the objectivity of the researcher, but also offers a field of visual play that formally furthers Steven Hill's theorizing on the idea of frames and what predetermines the frames theoretical, autobiographical, and otherwise, we bring to the project of art "for" social change.

The interview video Art For . . . seeks to represent what Doug and Ted Aoki (2003) see as the inherent hope of every interview: Which is, "to generate a new vision of the subject in the space of its own discourse" (p. 6). In this creative space, new meaning can be generated. In this space, a space that characterizes artistic inquiry, the viewers/listeners are called to interpret and reconsider their own responses; they cannot simply rely on habitual responses and are asked to re-think or re-frame their responses. This process in and of itself becomes an action site of research (Fels, 1998). And finally, my hope is that this digital video, as an artistic exploration, challenges us all to consider the seriousness of research in light of playfulness and invention.

\section{Art For ...}

Please follow this link to view the video:

https://ualberta.aviaryplatform.com/r/639k35n178 


\section{References}

Arendt, H. (1954). Between past and future: Eight exercises in political thought. Harmondsworth, UK: Penguin Books.

Aoki, T., \& Aoki, D. (2003) Interview. Educational Insights, 8(2) [Online]. Retrieved from:

http://einsights.ogpr.educ.ubc.ca/v08n02/celebrate/index.html

Balfron Social Club. (2015). Brutalism [redacted] - Social art practice and you [Website]. Retrieved from:

http://50percentbalfron.tumblr.com/post/116281372004/brutalism-redactedsocial-art-practice-and-you

Fels, L. (1998). In wind clothes dance on the line. Journal of Curriculum Theory, 14(1) 27-36.

Finklepearle, T. (2013). What we made: Conversations on art and social cooperation. London, UK. Duke University Press. 